
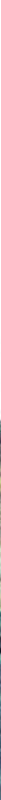
$5 \times 1.07$

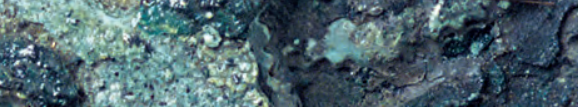
3

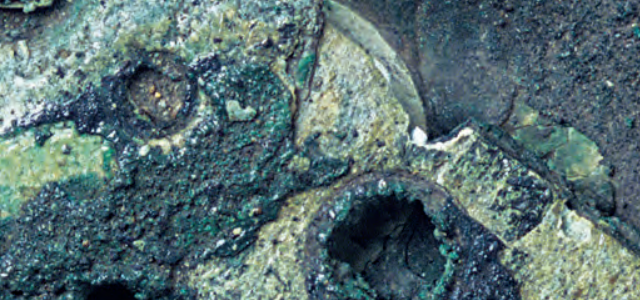

9. $x^{2}+x^{2}+2+5$

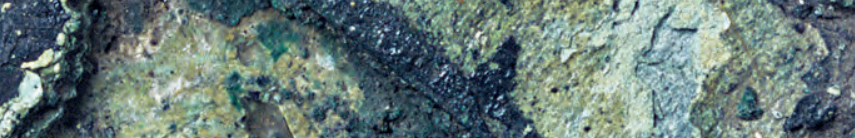

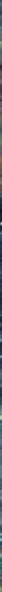




\title{
The Justice of the Chimaira: Goat, Snake, Lion, and Almost the Entire Oresteia in a Little Monstrous Image
}

\author{
JOHAN TRALAU
}

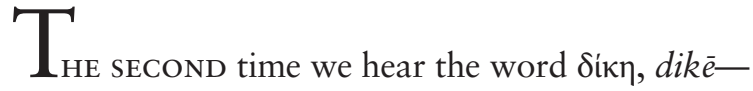
which usually means "justice"-in Aischylos' Oresteia, we may just read by, overlooking how strange an image it conveys. The tragic poet tells us that Agamemnon sacrificed his daughter Iphigeneia, ordering his servants to lift her above the

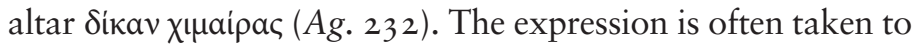
mean "like a one-year-old she-goat," a fairly simple simile comparing the killing of the woman to a normal sacrifice. Recently, as we will see, critics have pointed out that the wording could be understood as a reference to a mythic monster, the Chimaira. In the following, however, a new interpretation will be suggested. First, it will be argued that the words address the troubled relation between animals and justice in a very special way, and that the expression is consequently a wonderfully monstrous compound of two spheres that are, in the Greek cosmos, incommensurable. In short, the incongruent amalgamation of words in the expression, the incongruent body of the mythic creature alluded to in those words, and the incongruity of the spheres that coalesce in the human sacrifice all mirror each other. Second, it will be claimed that if we read the Oresteia through the lens of the Chimaira image, we will see a great part of the entire tale, from the prehistory of the Trojan war to the persecution of Orestes, in this three-bodied body, lion, goat and snake-that is, that the body of the monster incarnates the story told by Aischylos. If we accept this interpretation there are important implications for our understanding of Aischylos and his use of images in general. Aischylos' poetry is an exercise in massive sensory overload which defies most attempts to establish strict "ei- 
ther-or" interpretations. Yet the interpretation laid out below will provide a counter-understanding against some influential readings that emphasise the wild, promiscuous or arbitrary nature of his metaphors and similes. ${ }^{\mathrm{I}}$ I will try to show that Aischylos' imagery is intoxicatingly systematic in its use of monsters, images and animal species.

The argument will unfold in accordance with the body of the Chimaira. After relating previous scholarship, we will explore the hermeneutic potential of the image of the woman as a goat and the possibility of understanding her not only as a goat, but as the mythic creature from whose middle part a goat protrudes. We will then follow the lion imagery, continue with the series of images pertaining to snakes, and then go on to discuss conclusions and the implications of this interpretation.

PREVIOUS INTERPRETATIONS,

FROM STRAIGHTFORWARD IMAGES TO MONSTERS

THE IMAGE of the goat-girl is to be found at the beginning of Agamemnon, the first play in the trilogy. After a watchman,

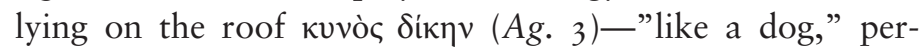
haps-has seen beacons signalling that Troy has fallen, the chorus sing of the Trojan expedition. Agamemnon, the king of Mycenae, was forced to sacrifice his daughter in order to assuage Artemis, who had been slighted and who hence prevented the Greek force from sailing on from Aulis to Troy. After the first choral song we witness how Agamemnon returns home and is murdered by his wife Klytaimestra and her lover, Aigisthos. In the second play, Agamemnon and Klytaimestra's son Orestes returns in disguise and retaliates. At the behest of Apollo, he murders his mother and her lover. $\mathrm{He}$ is then prosecuted by the Erinyes, the goddesses of revenge conjured by his mother. In the final play, Orestes reaches Athens where he is tried in court-specifically, the Areopagos institued by Athena for the purpose of trying homicide cases. Apollo and Orestes plead his case, the 
Erinyes plead theirs, the jury vote is tied, and Athena finally decides, acquitting Orestes. The Erinyes are then placated and introduced at Athens, where they will henceforth receive due honors and cult. So much for the story, which is the history-or rather, the great etiological myth-of the supersession of the archaic system of "private" retaliatory violence, and the advent of legal procedure and political authority in a narrower sense. ${ }^{2}$ The Oresteia is arguably, in the words of Christian Meier, the "großartigste Manifestation" of Hellenic political thought in the 5 th century. 3

The image of Iphigeneia being slaughtered "like a goat" in the first choral song has not always attracted much attention. Eduard Fraenkel claimed that it involves a comparison with a sacrifice before a battle, and that it is natural to liken Iphigeneia to a goat since she is made to serve a similar purpose in Aischylos' plot.4 This appears to be straightforward, but the question is if that is all there is to it. By contrast, Simon Goldhill has argued that the point of the image is that the young woman and the animal are not similar. 5 But the question is if the ximaıp in the passage must be taken to be a year-old she-goat. John Heath, in a brief footnote, states that the word could instead allude to the Chimaira, the mythic monster. ${ }^{6}$ In an innovative essay, Peter Wilson goes one step further.7 He draws attention to the fact that the construction of $\delta$ ícav with a genitive, hitherto almost invariably understood as an adverbial expression signifying similarity, is most unusual, that its overwhelming presence precisely in the Oresteia - and almost only there in extant Greek literature-is significant, and that it resonates with a larger theme in the trilogy and in Hellenic thought, that of law and ani-

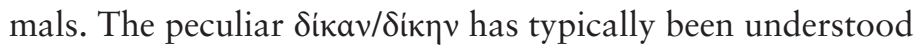
as a mere "quasi-preposition" meaning "like" or "in the manner of." ${ }^{\circ}$ But the expression is unusual and eccentric, and Nicole Loraux has pointed out that "le silence des commentateurs ... est remarquable" in this regard. 9 Others have downplayed the strangeness of the expression and its possible connotations vis-à-vis the theme of justice. ${ }^{\text {Io }}$ By con- 
trast, Wilson says that it is certainly telling that the human sacrifice in question is depicted by means of an image of a monster. I I Yet we need to ask of what this image is telling, what the point of the image is, that is, why Aischylos would want to employ the Chimaira in this context. In the following, a new interpretation will be ventured. Our answer will be twofold. First, this singular combination of words denoting a certain animal and justice, this conceptual "monstrosity," reveals the perceived monstrosity of the sacrifice and events depicted in the Oresteia. Second, the sequence of animals in the Chimaira's body mirrors the tale itself.

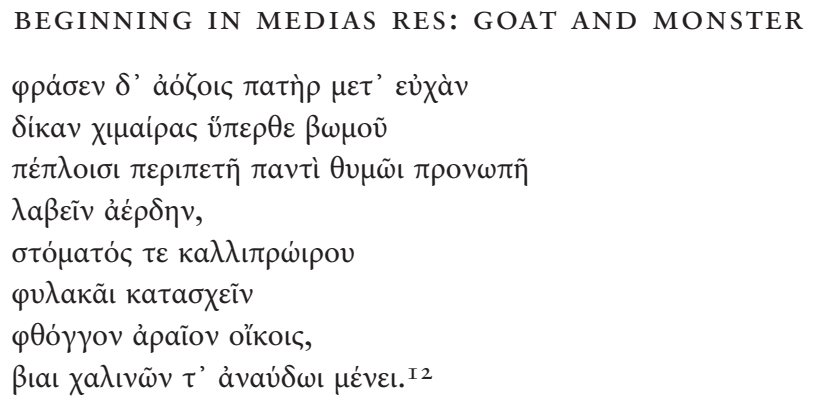

Her father, after a prayer, told his servants to lift her like a year-old she-goat over the altar with all their strength-facing down, her garment falling round her-and to restrain, with a guard on her beautifully-prowed mouth, any sound cursing the house, by the bridle's force and speechless power.

The scene is impressive, and so is the imagery. There are several remarkable metaphors. We learn that the servants gagged the woman so as to stop her from laying a curse on the

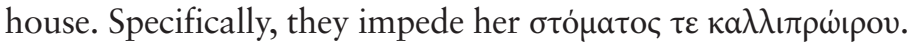
Sommerstein glosses these words as "her fair-prowed mouth," a naval metaphor of the body. Several commentators have let the expression pass without comment. ${ }^{2} 3 \mathrm{~J}$. D. Denniston and Denys Page argued that the word $\kappa \alpha \lambda \lambda \iota \pi \rho \omega$ เ example of its type, the compound adjective of which the lat- 
ter element is meaningless." I4 Fraenkel claimed that in this passage the $-\pi \rho \omega \rho \circ$ clement is employed as "simply the forward end of something." I5 D. van Nes has, however, pointed out that the prows of ancient ships actually resembled, and were thought of as, faces with their ram and painted eyes in front. ${ }^{16}$ And it could be argued that $\kappa \alpha \lambda \lambda \iota \pi \rho \omega$ ' prowed" is neither "meaningless" nor "simply the forward end" in this context. We know that the Greek expedition could not sail on from Aulis, and that this sacrifice was undertaken for the purpose of redemption. The word

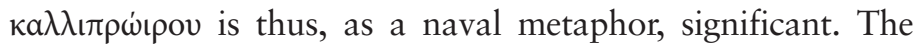
slaughtering of Iphigeneia instrumentalizes her, and it reduces her to a means that makes the further voyage of the Greeks possible. The victim is metaphorically reduced to an object, a ship, corresponding to the purpose of the sacrifice itself. This is, then, arguably a further indication that the order of the world has been subverted in the Oresteia: humans are not only treated as animals, but as things, as objects.

And these images continue their work. The young woman is

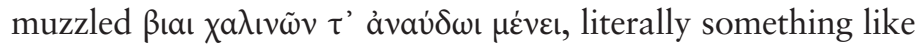
"by the force and speechless power of bridles." And ávavi $\delta \omega t$, "speechless," is probably a disconcerting word, not just in the sense that it describes the violent act of silencing the victim, but also because it evokes subversion of the cosmological hierarchy of animals and human beings. As forcefully argued by Heath, the Greeks conceptualized the radical difference between beasts and men as that of beings without language as opposed to those who possess language. ${ }^{17}$ "Speechless power" thus in a very special way resonates with the horrifying treatment of the woman as a sacrificial animal: it very explicitly, very symbolically turns her into what she as a human being is not meant to be. Moreover, the object, possibly cloth, with which she is controlled is likened to a bridle or bit, $\chi \alpha \lambda \iota v \tilde{\omega} v$ ( $\chi a \lambda$ เvós was used of both the bit and the bridle in general). ${ }^{18}$ In a different tragic context, Charles Segal has argued that the bit is a "traditional metaphor for civil order" and "self-control." I9 But this is simply not correct. When bits and bridles 
are to be found in tragedy, they are typically and-like yokes, goads and whips - unequivocally reminiscent of despotism, of political tyranny. ${ }^{20}$ Similar to the evocation of speechlessness, the metaphorical use of tools that are constructed for the purpose of controlling animals is deeply alarming when these tools are applied on humans. The image of the bit thus subverts political and cosmological order.

But most importantly, Agamemnon orders the servants to lift his daughter Síkav xuaipas (Ag. 232). Sommerstein, in his translation, renders it by "like a yearling goat." Some commentators seem to have found the expression less than spectacular, omitting any discussion of it. ${ }^{21}$ Others, such as Petrus Groeneboom, have just seen a touching image of the girl, a "beeld der weerlosheid," "an image of defenselessness." 22 Denniston and Page argue that the image is "specially apt, for it was customary to sacrifice a ximaıpa to Artemis Agrotera." 23 Likewise, Headlam and Thomson say that the she-goat was "the normal victim." 24 Yet like "apt," "normal" is of course, to begin with, a problematic concept in the context of human sacrifice. As has been noted, the image is "revolting to us" but must have been "more revolting still" to the Greeks, used to the sight of the bloody sacrifice of animals. ${ }^{25}$ The treatment of a woman as if she were a goat is, then, scandalous to Greek sensibilities. ${ }^{26}$ But as we will see, the words cannot (as has been suggested) plausibly be rendered by the unspecific "like some sacrificial animal." 27 It would appear that the species of this sacrificial beast is significant-or rather, possibly, the three species.

As we saw, two scholars have pointed to the possibility of understanding this ximaı monster named for it. ${ }^{28}$ Neither of them develops the implications of such an interpretation. Yet the Chimaira is a mysterious creature-perhaps more so than many others of Greek myth. Homer tells us that she is of "divine descent,"

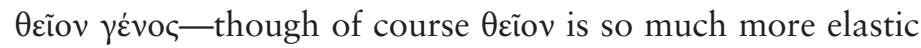
a concept than our "divine" - and has the body of a lion, a goat, a snake's tail, and that she breathes fire. ${ }^{29}$ Many find 
the combination of the fierce lion, the terrible snake and the domesticated she-goat alienating or ridiculous since the goat is not (seems not to be) as horrifying as the other species represented in the monster's body. 30 Jenny Strauss Clay thus argues that "there is an almost comic incongruity in the combination of a fierce lion and huge serpent with a young female goat-hardly a terrifying beast." ${ }^{\text {I }}$ In this vein, Martin West has claimed that the Chimaira is the "oddest and least satifying of the mythical monsters." 32 In Hesiod's Theogony the origins of the Chimaira are slightly enigmatic and unclear, or at least open to debate. 33

Why the Chimaira, then? Why this strange composite? How would it make sense to read Aischylos' expression as an allusion to the monstrous creature? The solution to this enigma is perhaps to be found in another strange composite, linguistic this time-in fact, the very words that we are

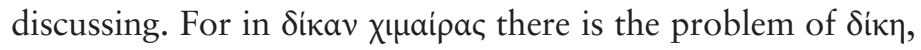
"right." Some have, as we said, denied the connotation of conceptions of "right" and "justice"—undeniably one of the

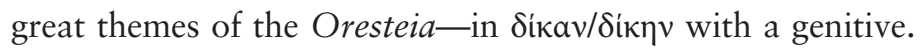
Garvie claims, in the context of such a construction in the Libation Bearers, that "it is going too far to connect this with

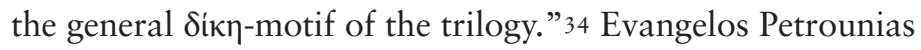
argues that the word "justice" is in fact to be heard in these constructions, yet adds that Aischylos does this for reasons of euphony, as a mere decoration. 35 Previous scholarship has thus typically downplayed the possibility of references to justice. The construction has most often been interpreted simply as "like" a goat, a dog, the moon and so on-in this vein, Groeneboom says that it equals трó "in the manner of." ${ }_{36}$ Yet even a brief inventory of such constructions in Greek shows us how unusual and peculiar they are. In Aischylos, almost all other examples are in the Oresteia itself, and outside of him, the only other tragic examples are from two Sophoklean fragments (one an image of a woman compared to a maltreated foal, the other to Sirius, the "dog star") and once in Euripides, once again in a 
comparison with an animal, an octopus.37 All animals and rights, then-but the "all" is a small number. Apart from that, the construction is used once in Pindar, Archilochos and Semonides. $3^{8}$ These are the instances enumerated by Wilson. It could be argued that he overstates the eccentricity of the expression, given the other examples. Moreover, one could add Anaximenes, who is reported to have said that the stars

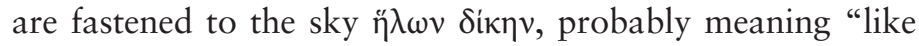
nail-heads," though the source, Aetios, is very late and possibly dubious. 39 Furthermore, Empedokles actually speaks of

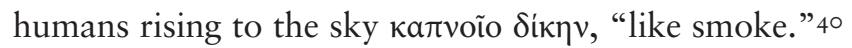

If the expression is probably not as strange as argued by

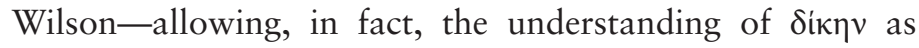

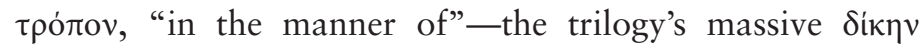
bombardment of the audience is in fact singular. And more recent scholarship has discovered new possibilities of interpretation pertaining to $\delta$ ín $v$ as right in the Oresteia. Wilson has argued that the wording is used to convey an image of a cosmological distortion, of a world in which the distinction between man and animal has been subverted.4I The Oresteia depicts a world of corrupted sacrifice, where humans beings are treated as if they were beasts. In the trilogy we thus find the expression in linguistic images pertaining to dogs, a goat or the Chimaira, the moon, dreams, a baby, barbarians, a swallow, a bride, a wave, a cow, a swan, a crow, a messenger, sailors, a child, the Gorgons, a hare, a fawn, a coachman and a gardener (and someone may wish to add blood).42 This is

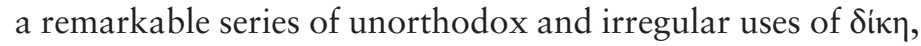
in a trilogy grappling with right, humans, and animals. Understanding the words at hand only as "like a goat" is arguably not plausible. On the contrary, we may expect something disconcerting.

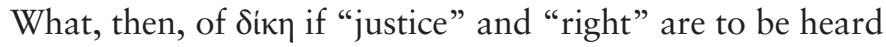

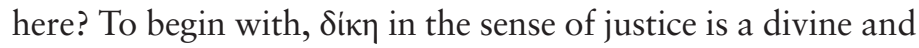
human affair. It does prima facie not pertain to the sphere of animals and their behavior. The combination of "right" and "animal" is hence, to mainstream Greek thought, a concept- 
ual aberration. In Hesiod's account of the order and ordering

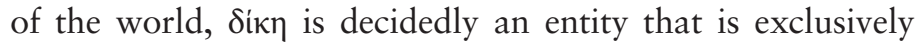
pertinent to humans and gods.

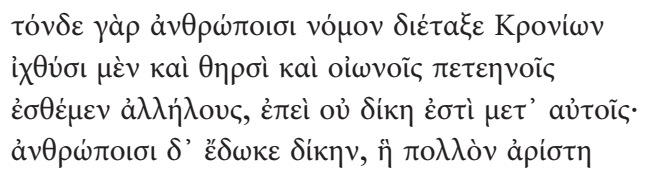

(Hes. Op. 276-79)

For the son of Kronos ordained this law for humans: fishes and beasts and winged birds eat one another, since right is not among them; but to human beings he gave right, which is by far the finest.

Hesiod thus explicitly opposes Sikn and the animals. The latter may devour each other; humans may not, for they partake in $\delta i \kappa \eta$ and are thus subject to it. It is surely significant that Hesiod chooses to present the moral distinction between man and animal in terms of eating. 43 Cannibalism is fine for fish, birds and so on. Animals and humans belong to different conceptual worlds in the sense that the former have no part in "right," except as objects of the acts of sacrifice that maintain social and cosmological harmony. The Greeks had no Holy Scripture, yet it is clear that Hesiod's etiological tale of sacrifice is as close as one comes to a standard account.44 And though there are exceptions to this fundamental principle of Greek morality-e.g., sectarian vegetarians such as the Orphics-this cosmology likewise underlies the universe of Aischylos. A polis is, as convincingly argued by Jean-Louis Durand, a community of people sacrificing together, united by virtue of the bloody public sacrifice of animals and the corresponding prohibition to spill the blood of others belonging to the community.45 Justice and beasts are thus radically different from each other. An expression such as Sikav

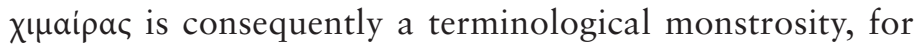
it connects the beast and justice. And in this sense, the wording mirrors the "object of comparison," the Chimaira. 
This monster is made up of parts belonging to different species. Homer sings in the Iliad:

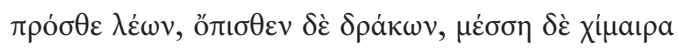

the fore part a lion, the back part a serpent, in the middle she is a goat

These species, goat, lion, snake, are unthinkable in one and the same animal, except in this curious deviation, deriving from the strange prehistory of the world, an epoch that still gave birth to monsters. And in the same vein, the conglomerate Sikav Xupaipas is composed of phenomena that do not belong together. $\Delta$ ikn on the one hand and the Chimaira or the goat on the other hand are parts of different conceptual spheres, the substance of which is determined by mutual exclusion. The expression thus reflects the monster involved in it. Just like the mythic creature itself, "the justice of the Chimaira" is a monstrosity-a conceptual monster created by Aischylos.

It could be objected that the Greeks had no real interest in

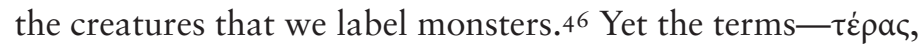
$\pi \dot{\varepsilon} \lambda \omega \rho$ - used of this group of mythic beings seem to mirror the conception of the monstrous inherent in many modern languages. They can be used of something terrifying, something huge, but also of something that is an aberration in being a mixed body, a hybrid the body parts of which are incommensurable in "natural" species.47 A conglomerate, then, a combination of things that do not belong together. In this exact sense, the Chimaira is a monster, and in this sense,

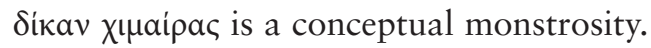

The point of this interpretation is not to argue that Aischylos' $\chi$ ía cally sacrificed to Artemis. $4^{8}$ The $\chi$ ina ably ambiguous, goat and monster-and of course, the monster reading presupposes the goat, as the middle part mediating between snake and lion. And intriguingly, the con- 
ceptual monstrosity mirrors that of the phantasmagorical creature itself, as well as the monstrosity of the atrocious act of treating a human being like a sacrificial animal.

No one has, to the best of my knowledge, ventured this interpretation before. Yet it resonates with and complements other, perhaps almost uncontroversial, strands of interpretation. For the world depicted in the Oresteia, before the trial and aquittal of Orestes and the incorporation of the Furies into the city-state, is one in which the relation between humans and beasts is distorted and perverted.49 In the following, as I said, we will look at images pertaining to lions and snakes, yet these are a part-though perhaps the dominant part-of an enormous web of animalic imagery that suggests that the world is out of joint. In the parode, the watchman will say nothing of what happens "in the house," adding that "a big ox has stepped on [stands on] my tongue,"

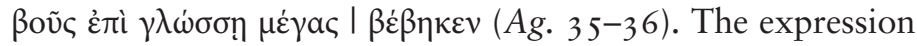
has been duly debated, and some have defended the view, originating in Pollux (9.6I) that the "ox" is the coin introduced by Theseus, sporting an ox, and that the expression thus implies that the silence of the watchman has been bought. $5^{\circ}$ It has, however, also been argued that the "ox" may just be a way of expressing how heavy the burden of silence is. ${ }^{\text {I }}$ Others have claimed that it is "a widespread proverbial phrase," or a "homely phrase." ${ }^{2}$ Given that there is but one single parallel in which we actually find an ox that has stepped on a tongue-in Theognis-the expression is still remarkable in the context of Agamemnon. The image of an ox stepping on a man's tongue is bizarre and terrible-particularly when we consider the great number of instances in which humans are treated as animals in the Oresteia. In the final phase of this theme, before the world appears to be wrestled back into order, the Furies repeatedly complain that they are treated like horses, and at one point they say that Klytaimestra drives a goad "up into the midriff, up into my

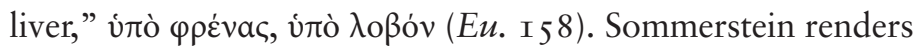


vंró as "up into," but it can of course imply place as well as direction, "under" or "in under," "up into." 53 Some commentators have hence chosen to understand the expression as "under," others as "up into." 54 Yet the goad would arguably not just be held, but pressed into the body, and this should make us sensitive to the hermeneutic possibilities inherent in "up into the liver" (metonymically, the lobe of the liver). Regardless of whether we visualize the Furies in their "natural," quasi-human shape or as metaphorical horses, this image is uncanny. 55 The horse's liver is well protected in its body, inside the ribs, and a goad that pierces the chest in that way would of course no longer serve the metaphorical purpose of prodding the horse in order to make it run faster. $5^{6}$ Clearly, then, the Furies-capable of speech and worthy of some sort of awe-are being treated in a way that is not even appropriate for an animal.57 The abyss between gods, humans and animals has been bridged, and the order of the world is thus distorted. The Chimaira may in fact be the perfect representation of this distortion, for it unites what must otherwise be kept apart.

UP FRONT, THE LION

IN Agamemnon, we find a much-discussed passage devoted to an image of a lion cub.

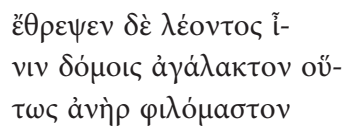

(Ag. 7I7-I9)

In this way a man nourished a lion child in his house, loving the breast yet deprived of its milk

Yet of course the lion then developed its true nature, and

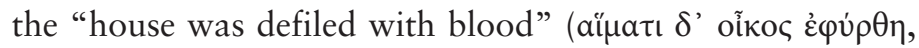
$A g$. 732). Interpretations of this ode have been diverse and divergent. The lion cub has been construed as an image of 
Helen and her destructive nature, as equally destructive Paris who received her in Troy, as Agamemnon-likewise destructive, in his own way-and as the events themselves. $5^{8}$ The passage involves an image of suckling: the lion cub is not fed by its mother, and as we shall see, this notion anticipates an image of breastfeeding that will be of great importance to the trilogy. We cannot deal with the complex problems of interpretation here, but will proceed on the assumption that all of these interpretations of the lion cub are at least possible, and may or should have been perceived as such by a Greek listener. Indeed, the lack of clarity in the image may be significant, for as we will see, Aischylos' images seem to contaminate each other. The image of the lion is transmitted from one character to another, in exact analogy to pollution. It may hence be quite appropriate for this original metaphorical lion to be indeterminate in its ascription to a particular character. In this drama, where boundaries are constantly transgressed, the distinctions between images and persons are likewise subverted. And regardless of the possibility of understanding the lion cub as Agamemnon, other images unequivocally connect the king and the great predator. 59 Agamemnon himself speaks of the conqueror at the sack of Troy in the image of a lion leaping over its walls-and he is of course himself the commander of this expedition $(\mathrm{Ag}$. 827). ${ }^{6}$ In prophetic frenzy, Kassandra speaks of the history and the terrible future of the house of Atreus, mentioning Klytaimestra, Aigisthos and Agamemnon: Klytaimestra is

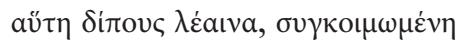

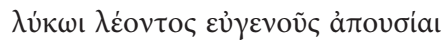

This is the two-footed lioness, who sleeps with the wolf in the absence of the noble lion

The absent lion must be Agamemnon. This creature is, we hear, ev̉yevoũc, noble. The Greek history of lion images is long, and one of the remarkable features of Agamemnon is 
arguably the extent to which the lion represents ferocity rather than a noble temper and valour-and this is probably the single unequivocal exception in the text. ${ }^{6 \mathrm{I}}$ The wolf sleeping with the lioness would appear to be Aigisthos, and the lioness is Klytaimestra. The cultural history of the wolf in ancient Greece is of great interest, but we cannot address it in this context.62 Two things are especially interesting. The first is that a metaphorical wolf sleeps with the adulterer-lioness, a transgression of species that would not occur in the realm of nature, and arguably a disconcerting image. The second is that the lioness is in fact a monstrosity: she is di $\pi$ ouc, "twofooted," an expression "presumably" deriving from "oracular language." 63 It has recently been claimed that this bipedality "underline[s] Clytemnestra's power." 64 Yet this kind of distortion of natural form and behavior is in fact pervasive in the Oresteia. Likewise, it is connected with a fundamental instability of species. For a little earlier, Aigisthos maythough the text is uncertain-be referred to as a "cowardly lion," $\lambda \dot{\varepsilon} 0 v \tau$ ' ăva $\lambda \kappa เ v$ in bed with Klytaimestra (Ag. I 224).65 As pointed out by Judet de la Combe, this is "contre les lois de la nature," yet makes perfect sense as a metaphor expressing the status of Aigisthos in the play. ${ }^{66}$ And as argued by Heath, the "blending of the two worlds," human and animal, bed and predator, is remarkable in this image. ${ }^{67}$ The leonine connotation begins in Helen, Paris or Agamemnon, passes on to Agamemnon, then to Klytaimestra, and from her to Aigisthos-from the prehistory of the Trojan war to its aftermath in the murder in the bath tub in Mycenae.

Yet the lion image continues. It morphs. In the Libation Bearers, at the moment when Orestes kills Klytaimestra, the chorus sing that a "twofold lion," $\delta i \pi \lambda$ ov $\lambda \dot{\varepsilon} \omega v$ (Ch. 938), has come. This "double lion," which surely recalls the two-

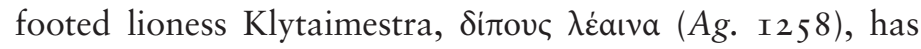
been much discussed. Some have argued that it refers to Klytaimestra again, or Klytaimestra and Orestes, while others have made the case that it signifies Orestes and Pylades, or indeed Orestes alone, or even the killing of 
Klytaimestra and Aigisthos. ${ }^{68}$ Garvie, who seems to choose none of these options, notes that the lion image "recur[s] with changing reference throughout the trilogy." 69 And as argued by Kurt Sier, the wording may be "mit Absicht paradox." 70 Perhaps we should read the opacity of this image of the "double lion" as well as that of the first leonine metaphor, the lion cub, as instances of systematic ambiguity. What begins in obscurity of reference and is transmitted through a chain of persons-Agamemnon, Klytaimestra, Aigisthos, Orestes-ends in obscurity of reference. The images have been passed on, like a contagion, polluting one character after another. The very last reference to a lion is to be found in the scene where Apollo ousts the Furies from his temple, saying that they should live in "the den of a blood-

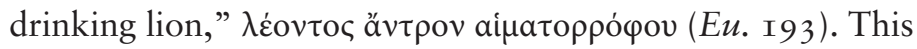
series of images ends, then, on a "dark note." ${ }^{\mathrm{I}}$ Apollo indirectly uses the predatory image of the Erinyes. But the serpentine imagery has already begun.

\section{AT THE END OF THE TALE, THE SERPENT}

ORESTES HAS appeared as a lion. As pointed out by Pierre Vidal-Naquet, he is a "personnage double . . . serpent et lion." 72 Yet this is not only true of Orestes. Like the lion imagery, the images pertaining to snakes are passed on from one character to the next. And this chain begins before Aischylos. In a fragment from the Oresteia of Stesichoros we encounter Klytaimestra and a remarkable snake.

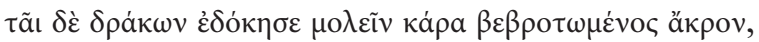

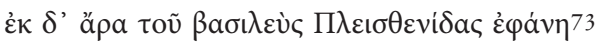

It seemed to her that a snake came, with the top of its head blood-stained, and from it a Pleisthenid king appeared.

Klytaimestra thus has a vision of a snake in a dream. The meaning of these verses is partly contested. It could, for 
example, be discussed to what extent the snake is only Agamemnon, and to what extent the Pleisthenid king mentioned in the fragment is Agamemnon, Orestes, or both, and whether the king emerges "from" the snake, or "after," or "in accordance" with it (whatever "it" would mean in the latter case). 74 Yet it would appear to be clear that the snake represents Agamemnon; the blood on the head is thus from the wound inflicted by Klytaimestra.75 The question why the dead man returns as a snake could likewise be discussed. 76 But the purpose here is not to solve any of these problems. Rather, the point is that in a poem that is at least a century older than Aischylos' trilogy, we probably find Agamemnon in serpentine form. We may surmise that Aischylos and at least some of his readers were aware of the older image, and that we should be, too. And in the tragic trilogy we find a remarkable chain of metaphors and similes pertaining to snakes.

Overcome by frenzy, at the beginning of Agamemnon, Kassandra is at a loss about what to call Klytaimestra:

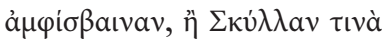

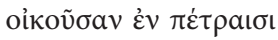

(Ag. I 233-34)

A double-headed snake, or a Scylla living among rocks

The a $\mu \varphi$ ioßaıva is part of the complex of serpents. Yet the word adds a very special flavor to this series of images, for as we learn in Aelian's book on animals and other places, the

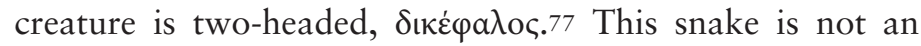
ordinary monster, and Klytaimestra is not an ordinary snake. ${ }^{8}$ The amphisbaina had two heads in the sense that it had heads at both ends, making head and tail double and the same. This evokes another aberration, the two-footed lioness Klytaimestra (Ag. I258), and it is, in the context of a wife and mother, alarming. It is also part of the pattern of perversion of natural and cosmic order that pervades the world of the Oresteia.79 Head and tail have been reversed in a 
strange fashion, and this is arguably a very sensitive issue in Hellenic culture. Admittedly a later source, and in a particular context, Aelian tells us that the initiates of the "two goddesses" were not allowed to eat the shark called $\gamma \alpha \lambda$ có s since that fish engenders or bears its young in or from the mouth

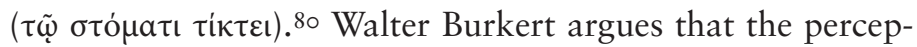
tion of this animal's impurity derives from the fact that the boundary between the mouth and the genitals-and hence sexuality-has been blurred.8I The snake does not, of course, mate with the tail, but a similarly provocative inversion of natural order may be at play in the notion of the amphisbaina, a disconcerting quality in the mythic monster.

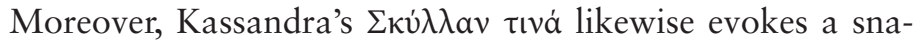
kish creature. And in Libation Bearers, Elektra speaks of her mother as a viper ( $\delta \varepsilon \imath v \tilde{\eta} \varsigma \dot{\varepsilon} \chi \dot{i} \delta v \eta \varsigma, C h .249)$ that has killed the eagle Agamemnon in its coils. ${ }^{82}$ After the murders, Orestes compares his mother to "a moray or a viper," $\mu$ ípaıvá $\gamma^{\prime} \varepsilon i \tau^{\prime}$ " $\chi\llcorner\delta v$ ' (Ch. 994), the former being understood as analogous to a snake. ${ }^{83}$ This prepares the transition of the snake from Klytaimestra to Orestes.

The most famous set of images of snakes is found in Klytaimestra's dream, and this is where the serpentine properties are passed on from mother to son. The chorus relate the vision in the dream to Orestes. Klytaimestra had given birth to a snake and wrapped it in swaddling-clothes "like a

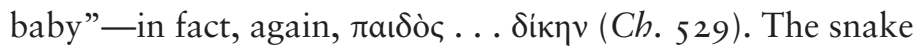
is ostentatiously problematic in the context of $\delta i \mathrm{k \eta}$, and so, arguably, is the child; the infant is not yet capable of participating in justice. Again, it would seem that "like a baby," "comme un enfant" 84 misses something fundamental, namely, the conceptual distortion inherent in the expression. And the image of the serpentine child turns nightmarish. Klytaimestra offers it her breast to suckle: aủंทे $\pi \rho 0 \sigma \varepsilon \dot{\sigma} \sigma \varepsilon$

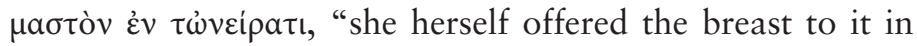

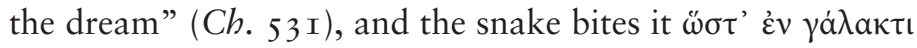

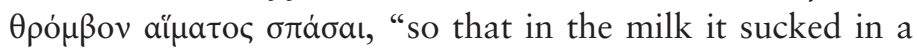
clot of blood" (Ch. 533). This grotesque image of a human 
mother and a baby snake signals inversion of the natural order in so many ways. Snakes are of course not mammals and do not suckle, and the vision of a reptile biting the breast of its human mother, mingling milk and blood, is extraordinary.

Orestes then interprets the dream:

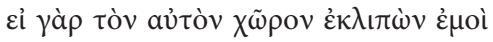

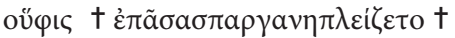

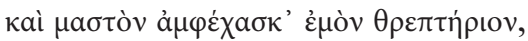

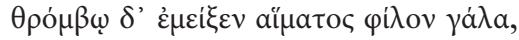

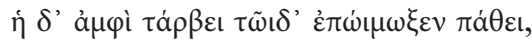

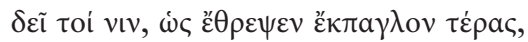

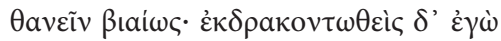

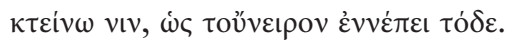

(Ch. 543-50)

If the snake had come out from the same place as I, and [wording and sense unclear] coiled up in my swaddling-clothes, and gaped its mouth around the breast that nurtured me, and mingled the loving milk with a clot of blood, and she cried in terror of what happened-then, surely, she must die violently as she nourished this terrible monster. Having become a serpent, I kill her: this is thus what the dream says.

Orestes takes on the role of the serpent. ${ }^{85} \mathrm{He}$ interprets the monstrous snake, calling it precisely $\tau \dot{\text { ćpa }}$, a "monster," and identifies it as himself. The chorus will directly thereafter say that he is a тєрабко́тос (55I) in this matter-the "diviner," or "portent-seer" or "monster-seer." Orestes is the seer and the object of the vision. ${ }^{86} \mathrm{He}$ is the snake that "gapes

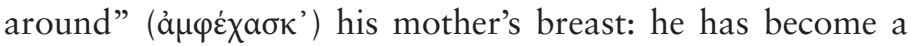
serpent ( $\dot{\varepsilon} \kappa \delta \rho \alpha \kappa o v \tau \omega \theta \varepsilon \dot{\varepsilon})$. The order of the family has been distorted, and it has become snakelike. ${ }^{87}$ The pollution of the snake has thus been transmitted from mother to son. It is probably fair to emphasize the fundamental inversion involved in an image of a suckling serpent, and it clearly echoes the image of the lion cub, in which there was likewise a problem with suckling, since the animal was somehow deprived of its mother's milk. 
It is often argued that the snake images play only a minor role in the Eumenides. ${ }^{88}$ The Erniyes are of course serpentine, as pointed out by Orestes (Ch. I050) and as often seen in the visual arts. ${ }^{89}$ Yet it is important to see precisely how the snake figures in the final passage in which a serpent is explicitly involved. When evicting the Erinyes from his temple, Apollo threatens them with his bow, saying that he

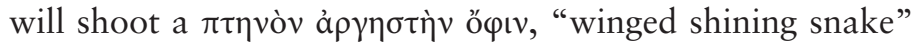
(Eu. I 8I) at them, a projectile that, following the scholiast, is a snake because of its bite or because of its venom. 90 This is a bold kenning sporting the arrow as a flying snake"bombast" according to Podlecki.91 Groeneboom claims that the fact that the object is winged is "een compromis" between the two images involved, that is, that the arrow is winged and that the snake is hence given wings to correspond to the arrow in the metaphor. 92 But the snakish arrow is particularly noteworthy in this context, for it is a link in the chain of serpents. The snake-beginning, perhaps, in Agamemnonpasses on from Klytaimestra to Orestes, then to her Erinyes, and finally ends up in Apollo's hand. It is as if the serpent pollutes, just like the lion.

We have thus seen that the drama can, up to this point, be traced through the image of the Chimaira. The sacrifice pictures Iphigeneia as a goat and as a monster, pointing toward the lion and the snake. Until the arrival at Athens, the main characters are all polluted by the lion and the snake. Lion, goat, snake. It is all there. And at the end of this part of the tale, we are reminded of the fact that the Chimaira breathes fire.

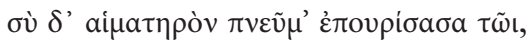

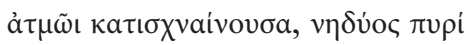

(Eu. $137-38)$

Blowing your bloody breath at him, making him waste away with your breath, with the fire of your bowels

In this passage, Klytaimestra evokes the breath of the Erinyes as one of fire, $\pi v \rho i .93$ The snakish creatures exude 
fire, they breathe "with fire," that is, they breathe fire. This completes the image of the Chimaira.

There is one final point to make. At one juncture, Klytaimestra says that if the reports and rumors of Agamemnon's death that circulated had been true, then he

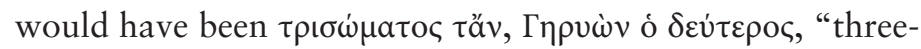
bodied-a second Geryon" (Ag. 870). Geryon was a monstrous man with three bodies, or heads, in different versions, yet always unnaturally tripled in some way-in this

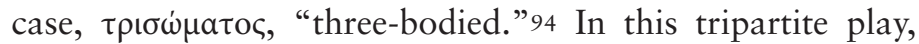
Klytaimestra, who is likened to several deformed creatures, a biped lioness ( $A g$. I 258) and a two-headed snake ( $A g$. I233), speaks of her husband-who has slaughtered their daughter like a goat or a three-bodied monster, the Chimaira-as a three-bodied being, Geryon. It is perhaps not incidental that the three-bodied Geryon belongs to the descendants of Phorkys and Keto, the same monstrous lineage as - the Chimaira.95

\section{CONCLUSIONS}

IN THIS PAPER, it has been argued that the expression Sikav

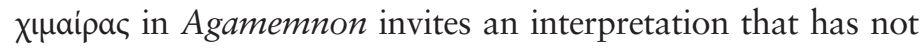
been made before. First, the wording - using the image of a hybrid monster, composed of bodies from different animal species that do not belong together-mirrors the incompatibility of the spheres of animals and justice, and the fundamental inversion that has taken place in a world where humans are treated as animals. Second, the possibility of reading the

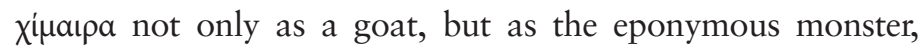
unveils a new perspective on the animal imagery; it reveals that the lion and snake images, mediated by the goat in the middle, organize the Oresteia. If this is true, then the strange expres-

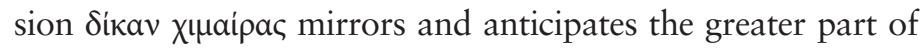
the trilogy-it incorporates and presents the fundamental perversion of the Greek concept of right. This is not to say that all animal images, or the plot as a whole, can be subsumed under 
this organizing master image. But the importance of the Chimaira has, to put it cautiously, been underestimated.

Are there other, grander implications? Perhaps. First, conclusions could be drawn about the role of monsters in Greek poetry and myth. While some scholars have argued that "monsters disproportionately attract the attention of modern readers," our reading would suggest that the Chimaira is of great importance in the play in shaping the imagery of the trilogy.96 The upshot would be that Aischylos himself found monsters good to think with.

Second, this interpretation may make us revise opinions about Aischylos as a creator of images and as a thinker. It has sometimes been claimed that the poet is not sophisticated, but rather a natural, primitive genius: Denniston and Page famously argue that "profound thought is not among [Aischylos'] gifts"; moreover, they state that "image and reality are sometimes rather confused than blent in Aeschylean metaphors." 97 And for what it is worth, it could be added that Mark Griffith has claimed that the tragedian has "relatively little interest in . . logical consistency." 98 Moreover, the nature of Aischylean images has been contested, with some scholars arguing that they are obscure and over-complicated.99 But it is important to see how coherent and systematic the imagery of the Oresteia is-promiscuous, indeed contagious, when animal species are transmitted from character to character, yet at the same time highly systematic. It illustrates, indeed embodies, pollution; the corruption and desecration are consistently transmitted along a chain of characters.

Third, and compatible with the tendency that we have just discussed, in Aischylos studies there is sometimes a tendency to downplay the precise nature of-and species inAischylos' images. Certainly, some scholars have claimed that Aischylos' metaphors surpass those of Sophokles and Euripides in precision. ${ }^{\text {Io० }}$ Yet the opposite case has been made more often. In this vein, it has been argued that in the Oresteia, the very fact of transgression of the border 
between humans and animals is much more relevant than "exact analogies," and that the "melding with animals" is what is important, not the specific animal species-goats, lions, snakes, and so on-involved. ${ }^{\text {го }}$ Likewise, it has been claimed that it is "sometimes an error to regularize these images," that is, to look for precision in them. ${ }^{102}$ Moreover, in a slightly different context, yet with regard to Greek myth, it has been suggested that it is often a mistake to try to under-stand an image on the basis of the particular kind of plant or animal, etc., used therein-we should, rather, consider such images "signposts" signalling an important passage. ${ }^{103}$ Yet as we have seen, the image of the Chimaira in Aischylos is astonishingly precise in operating precisely with different species for the purpose of showing a spectacular inversion of the conceptual and politico-religious order of the Athenian polis. His poetry, as an intervention into the Hellenic imaginary, operates with promiscuous yet at the same time exuberantly exact images.

\section{NOTES}

I. E.g., as we will see, J. D. Denniston \& Denys Page, eds., Agamemnon (Oxford I957), xv, ad I260-6I, I 85; Mark Griffith, "The Poetry of Aeschylus (in its Traditional Contexts)," in Jacques Jouanna \& Franco Montanari, eds., Eschyle à l'aube du théâtre occidental: neuf exposés suivis de discussions, Entretiens sur l'Antiquité classique LV (Geneva 2009), I-55, at $3 \mathrm{I}$. The author would like to thank Dimitrios Iordanoglou and Jasmina Nedevska Törnqvist for helpful comments on an earlier incarnation of this essay. All translations are mine.

2. To what extent it anticipates "modern" understandings of law can be discussed. Cf. Vittorio Hösle, Die Vollendung der Tragödie im Spätwerk des Sophokles: Ästhetisch-historische Bemerkungen zur Struktur der attischen Tragödie (Stuttgart \& Bad Canstatt I984), 5 I; Danielle Allen, The World of Prometheus: The Politics of Punishing in Democratic Athens (Princeton 200I), 2 I.

3. Christian Meier, Die Entstehung des Politischen bei den Griechen (Frankfurt/Main I983), I44.

4. Eduard Fraenkel, ed., Aeschylus Agamemnon, II (Oxford I950), I22, ad loc.; Denniston \& Page (note I), 89.

5. Simon Goldhill, Language, Sexuality, Narrative: The Oresteia (Cambridge I984), 3 . 
6. John Heath, The Talking Greeks: Speech, Animals, and the Other, in Homer, Aeschylus, and Plato (Cambridge 2005), 24I, n.4I.

7. Peter Wilson, "Dikèn in the Oresteia of Aeschylus," in John Davidson, Frances Muecke \& Peter Wilson, eds., Greek Drama III: Essays in Honour of Kevin Lee, BICS, Supplement 87 (London 2006), I87-201, at I96.

8. Anne Lebeck, The Oresteia: A Study in Language and Structure (Cambridge, MA I97I), 72.

9. Nicole Loraux, "La métaphore sans métaphore à propos de l'Orestie," RPhilos, CLXXX, 2 (I990), 247-68, at 259, cf. 26I.

Io. A. F. Garvie, ed., Choephori (Oxford I986), 94; more cautiously H. Robertson, "Legal Expressions and Ideas of Justice in Aeschylus," CPh, XXXIV, 3 (I939), 209-I9, at 2 I9 n.8.

II. Wilson (note 7), I87-20I, at I96.

I2. Ag. 23 I-39. I use West's Teubner edition.

I3. Jean Bollack \& Pierre Judet de la Combe, eds., L'Agamemnon d'Eschyle: Le texte et ses interprétations, I:2 (Lille I98I), 295-98; P. Groeneboom, ed., Aeschylus' Agamemnon (Groningen 1944), I65, Walter Headlam \& George Thomson, eds., The Oresteia of Aeschylus (Prague 1966), 24.

I4. Denniston \& Page (note I), 90, ad $234 \mathrm{ff}$.

I 5 . Fraenkel (note 4), I34-35, ad 235.

I6. D. van Nes, Die maritime Bildersprache des Aischylos (Groningen I963), 99.

I7. Heath (note 6), passim.

I8. X. Eq. iii.2, vi.9.

I9. Charles Segal, Tragedy and Civilization: An Interpretation of Sophocles (Norman, OK I999), I05.

20. S. Ant. 29I, 350-35I, 477-478; cf. Ai. 944; El. I462; and A. Ag. I6I 8, I624, I632, I640; Pers. 50, 72; Pr. 562, 597, 672, 682, 693, I009-IO.

2I. Bollack \& Judet de la Combe (note I3), 294-95; Florence Dupont, L'insignifiant tragique: Les Choéphores d'Eschyle, Electre de Sophocle, Electre d'Euripide (Paris 200I), 74; cf., e.g., Sven Dahlgren, De Aeschyli metaphoris et similitudinibus a re navali deductis commentatio (Stockholm I875), 25.

22. Groeneboom (note I3), I64, ad loc.

23. Denniston \& Page (note I), 89.

24. Walter Headlam \& George Thomson, eds., The Oresteia of Aeschylus (Prague I966), 24, ad 232-34.

25. R. P. Winnington-Ingram, Studies in Aeschylus (Cambridge I983), 82.

26. Sven Dahlgren De imaginibus Aeschyli, I, Commentatio academica, (Stockholm I 877), 80-8I.

27. As does D. J. Conacher, Aeschylus' Oresteia: A Literary Commentary (Toronto I987), I 5 . 
28. Heath (note 6), 24I n.4I; Wilson, (note 7), I96.

29. Il. 6.179-82.

30. A similar deliberation is found in Hor. Ars, I-5.

3I. Jenny Strauss Clay, Hesiod's Cosmos (Cambridge 2003), I 57.

32. Martin West, ed., Works \& Days (Oxford I978), 255.

33. D. Lemke, "Sprachliche und strukturelle Beobachtungen zum Ungeheuerkatalog in der Theogonie Hesiods," Glotta, XLVI, I-2 (I968), 47-53; Ernst Siegmann, "Xímaıpa, Hesiod Theog. 319," Hermes, XCVI, 5 (I968), 755-57.

34. A. F. Garvie (note I0), 94.

35. Evangelos Petrounias, Funktion und Thematik der Bilder bei Aischylos (Göttingen I976), 404 n.804.

36. Groeneboom (note I3), I I 8 , ad I-3.

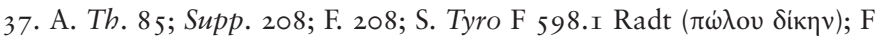
803 Radt; E. Hec. I 62.

38. Arch. 24(a); Semon. I2W; P. I.50.

39. DK I3 A I4; Aetios II, I4,3 Mansfeld-Runia.

40. DK 3 I B 2. Cf., by the way, and for what it is worth, Ovid's curious words about the octopus' changing color sub lege loci (Ov. Hal. 33).

4I. Wilson (note 7), I 88. Cf. Froma Zeitlin: "The Motif of the Corrupted Sacrifice in Aeschylus' Oresteia," TAPhA, XCVI, I965, 463-508.

42. Ag. 232, 297, 49I, 724, 9I9, 980, I050, I093, II79, II8I, I 298, I444, I472-73; Ch. I95, 202, 446, 529, I048; Eu. 26, I I I, I 56, 9I I (and 752 for blood, though I would disagree with Wilson [note 7], 200).

43. Marcel Detienne, Dionysos mis à mort (Paris I998), I4I.

44. Jean-Pierre Vernant, "A la table des hommes: Mythe de fondation du sacrifice chez Hésiode," in La cuisine du sacrifice en pays grec, Marcel Detienne \& Jean-Pierre Vernant, eds. (Paris I979), 37-I32, at 45.

45. Jean-Louis Durand, "La mort, les morts et le reste," in Systèmes de pensée en Afrique noire. Destins de meurtiers, XIV (I997), 39-56, esp. 42.

46. Ken Dowden, The Uses of Greek Mythology (London \& New York I998), I33.

47. Johan Tralau, Monstret $i$ mig: Myter om gränser och vilddjur (Stockholm 2015), 20-23; Il. 5.742, I 2.202, Od. II.634, Hes. Th. I 59, I79, 295-96, 479, 86I; E. Hipp. I2I4, A. Ag. 225.

48. Vincent Rosivach, The System of Public Sacrifice in Fourth-Century Athens, American Classical Studies, XXXIV (Atlanta I994), 57; Michael Jameson, "Sacrifice and Animal Husbandry in Classical Greece," in Pastoral Economies in Classical Antiquity, CPS Suppl. XIV, C. R. Whittaker, ed. (Cambridge I988), 87-I20, at 92.

49. E.g., Zeitlin (note 4I); Heath, The Talking Greeks (note 6), 226.

50. Jean Dumortier, Les images dans la poésie d'Eschyle (Paris I935), I 8 I; Plut. Thes. $25 \cdot 3$. 
5I. Groeneboom (note I3), I 25, ad 36-37.

52. Fraenkel (note 4), 23, ad 36-37. (citing Thgn. 8I 5, A. Fr. 3 I 6 Radt; S. OC I05 Iff; Stratt. Fr. 67/72); Denniston \& Page (note I), 70, ad 36-37.

53. $\lambda$ oßó is the lobe of the liver, but "here seems to denote the liver as a whole" (Alan Sommerstein, ed., Aeschylus Eumenides (Cambridge 1989), I I I, ad I 58 .

54. E.g., Headlam \& Thomson (note 24), I95, ad I55-I6I, who curiously omit the goad in their translation, and Anthony Podlecki, ed., Aeschylus: The Eumenides (Warminster I989), I43, ad I 58 , respectively.

55 . By contrast, Goldhill (note 5), 2I6, speaks only of "repetitions, alliterations" in this context.

56. Groeneboom notes that a wound in the liver can be lethal, but does, like most commentators, not develop the implications of the image (P. Groeneboom, ed., Aeschylus' Eumeniden [Groningen 1952], II7, ad I 55-6I). It is difficult to see how one can argue that the image of the Furies being whipped is a "fortiorem imaginem" (Dahlgren [note 26], 92) than that of the goad in the liver.

57. The bridles and bits that the Greeks used were sharp, yet their treatment of horses was not (or so Xenophon's manual on horsemanship suggests) as a rule unnecessarily harsh (X. Eq. 6.7-8; 9.9; IO.I, 8-IO; I I.6).

58. For these three interpretations, see Headlam \& Thomson (note 24), 62-63; Christopher Nappa, "Agamemnon 717-36: The Parable of the Lion Cub," Mnemosyne, Fourth Series, XLVII, I (I994), 82-87; Bernard Knox, "The Lion in the House (Agamemnon 7I7-36 [Murray])," Classical Philology XLVII, I (I952), I7-25; Denniston \& Page (note I), I35, ad 744ff respectively_cf. more cautiously, Groeneboom (note I3), 237, ad 7 I $7 \mathrm{ff}$.

59. Dumortier (note 50), I 5 I.

6o. Michel Fartzoff has argued that Agamemnon's moral ambiguity is mirrored in the Trojan campaign as well; see "Troie dans l'Orestie d'Eschyle: L'adaptation dramatique d'une image ambivalente," in Reconstruire Troie: Permanence et renaissances d'une cité emblématique (Besançon 2009), I67-85.

6I. Contrast, e.g., Il. I6.823-28.

62. Cf., however, Marcel Detienne \& Jesper Svenbro, "Les loups au festin ou la cité impossible" in La cuisine du sacrifice en pays grec (note 2I), 2 I 5-37.

63. Fraenkel (note 4), 580, ad I258. Pierre Judet de la Combe, L'Agamemnon d'Eschyle: Commentaire des dialogues (Villeneuve d'Ascq, Nord 200I), 54I, ad I258, cautiously defends $\delta i \pi \lambda$ ovc.

64. Daniel B. Levine, "Acts, Metaphors, and Powers of Feet in Aeschylus's Oresteia," TAPhA, CXLV (20I 5), 253-80, at 26I.

65. Fraenkel (note 4), 56I-62, interestingly, had a hard time accepting

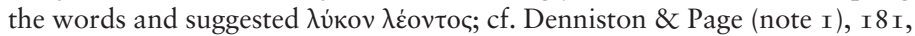
ad 1224 . 
66. Judet de la Combe (note 63), 523-24, ad I 224.

67. Heath (note 6), 225.

68. Dumortier (note 50), I $5 \mathrm{I}$.

69. Garvie (note I0), 306, ad 935-38.

70. Kurt Sier, Die lyrischen Partien der Choephoren des Aischylos: Text, Übersetzung, Kommentar (Stuttgart I988), 287, ad 938.

7I. Heath (note 4), 239; Sommerstein (note 53), II6, ad I93.

72. Pierre Vidal-Naquet, "Chasse et sacrifice dans l'Orestie d'Eschyle," in J.-P. Vernant \& P. Vidal-Naquet, eds., Mythe et tragédie en Grèce ancienne, I (Paris 200I), I33-58, at I 54: "Les serpents reparaissent, il est vrai, sur la tête des Erinyes."

73. Stesich. 2 I9 PMG.

74. Ulrich vonWilamowitz-Moellendorf, Aischylos-Interpretationen (Berlin I9I4), I9I-92; Ada Neschke, "L'Orestie de Stésichore et la tradition littéraire du mythe des Atrides avant Eschyle," AC, LV (I986), 283-30I, at 297.

75. Dumortier (note 50), 92; Karl Reinhardt, Aischylos als Regisseur und Theologe (Bern I949), I 27.

76. Martin Bock, "Die Schlange im Traum der Klytaimestra," Hermes, LXXI, 2 (I936), 230-236; C. Robert, "Zu Aischylos Orestie," Hermes, XXXVIII, 3 (I903), 629-37; Herbert Eisenberger, "Der Traum der Klytaimnestra in Stesichoros Oresteia," GB, IX, I (I980), I I-20, at I9.

77. Ael. NA 9.23.

78. Judet de la Combe (note 63), 530, ad I233.

79. Marianne Govers Hopman, Scylla. Myth, Metaphor, Paradox (Cambridge 20I2), I 6 .

80. Ael. NA 9.65; this shark was evidently an object of interestAnaximander claims that the human species was first engendered in the same way as the $\gamma a \lambda \varepsilon$ oi (DK I2 A 30 ).

8I. Walter Burkert, Homo Necans: Interpretationen altgriechischer Opferriten und Mythen (Berlin I997), 3 I 5.

82. Cf. K. O’Neill, "Aeschylus, Homer, and the Serpent at the Breast," Phoenix, LII, 3-4 (I998), 216-29, at 220.

83 . For the similarity, cf. Arist. $I A 707$ b29-708a2.

84. Dumortier (note 50), 46.

85. Garvie (note I0), I93, ad 549.

86. Deborah Roberts, "Orestes as Fulfillment, Teraskopos, and Teras in the Oresteia," AJPh CVI, 3 (I985), 283-97, at 290.

87. Florence Dupont, L'insignifiant tragique: Les Choéphores d'Eschyle, Electre de Sophocle, Electre d'Euripide (Paris 200I), 76-78.

88. Heath (note 6), 238 n.59; Dumortier (note 50), 98.

89. Cf., e.g., an Apulian oinochoe, Louvre K 320; Anneliese KossatzDeissmann, Dramen des Aischylos auf westgriechischen Vasen (Mainz I978), 94, 99 . 


\section{7}

90. Sommerstein (note 53), II4, ad I8I.

9r. Podlecki (note 54), I44, ad I8I.

92. Groeneboom (note 56), I2I, ad I79-83.

93. Groeneboom, (note 56), I I4 n.3, ad I33-39, points out the simila-

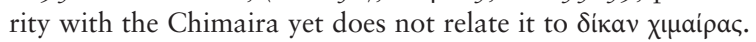

94. Apollod. 2.5.10.

95. Hes. Th. 270-319.

96. Dowden (note 46), I33; cf. René Huyghe, L'art et l'âme (Paris I960), 480.

97. Denniston \& Page (note I), xv, ad I260-6I, I8 5.

98. Griffith (note I), 3 I.

99. Maurice Croiset, Eschyle: études sur l'invention dramatique dans son théâtre (Paris I928), 35, cf. 37, speaks of a "fâcheuse obscurité."

I00. Dumortier (note 50), 266; Dahlgren (note 2I), I4.

Iог. Heath (note 6), The Talking Greeks, 229, 232.

I02. Lebeck (note 8), 65 .

I03. Radcliffe Edmonds, "The Bright Cypress of the "Orphic" Gold Tablets: Direction and Illumination in Myths of the Underworld," in Menelaos Christopoulos, Efimia Karakantza \& Olga Levaniouk, eds., Light and Darkness in Ancient Greek Myth and Religion (Lanham 2010) 22I-34. 


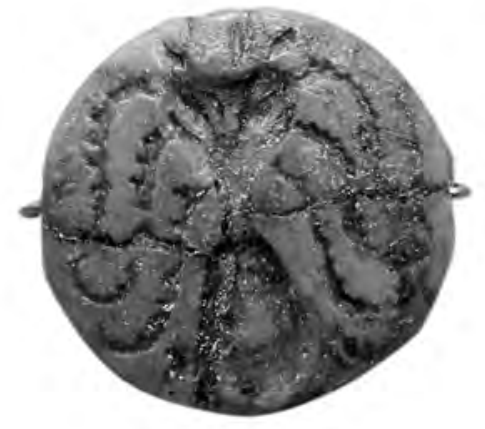


